\title{
Perilaku Dalam Pengelolaan Sampah Dan Kondisi Layanan Pengelolaan Sampah Kota Malinau
}

\author{
Nuzula Elfa Rahma* \\ Program Studi Pengelolaan Lingkungan, Politeknik Pertanian Negeri Samarinda, Samarinda 75242 \\ elfarahma@gmail.com \\ *Corresponding author
}

\begin{abstract}
Abstrak - Tujuan penelitian ini adalah untuk mengetahui praktik-praktik yang dilakukan masyarakat Kabupaten Malinau dalam pengelolaan sampah serta persepsi mereka terhadap layanan pengelolaan sampah yang telah dilakukan. Penelitian ini menunjukkan dari segi praktik pengelolaan sampah, masyarakat Kota Malinau relatif telah sadar akan pentingnya menjaga kebersihan, meski belum sepenuhnya terimplementasi dalam tindakan. Membuang sampah pada tempat yang telah disediakan diakui telah dilakukan oleh sebagian besar masyarakat. Perilaku keliru dalam membuang sampah yang paling umum dilakukan adalah membuang sampah ke sungai, serta di fasilitas umum yang ramai seperti pasar. Selain itu, pengelolaan sampah secara komunal relatif belum dilakukan. Di sisi lain, ada pula praktik positif yang telah dilakukan masyarakat Malinau sejak lama, yaitu pemanfaatan sampah dapur dan sisa makanan menjadi pakan ternak. Di samping itu, praktik pengelolaan sampah swadaya yang terorganisir dengan baik dapat ditemukan di sekolah-sekolah. Sedangkan untuk layanan pengelolaan sampah kota yang dilakukan dinas terkait, masyarakat umumnya mengeluhkan kurangnya jumlah TPS yang layak serta perlunya peningkatan frekuensi dalam kedisiplinan dalam pengangkutan dan pengumpulan sampah ke TPA. Untuk pengembangan layanan pengelolaan sampah ke depan, pemerintah setempat perlu pula melakukan upaya aktif lebih untuk mendorong partisipasi masyarakat untuk melakukan pemilahan dan pengumpulan sampah yang baik di tingkat rumah tangga, seperti yang diarahkan dalam prinsip $3 \mathrm{R}$ (Reduce, Reuse, dan Recycle).
\end{abstract}

Kata Kunci- pengelolaan sampah, Malinau, persepsi masyarakat

\section{Pendahuluan}

Meski kepadatan penduduk di Kabupaten Malinau masih relatif kecil, masyarakat Malinau telah berkembang menjadi masyarakat yang heterogen. Terlihat dari latar belakang masyarakat yang sudah cukup beragam, terutama dari segi etnis, agama, tingkat pendidikan, dll. Fenomena ini tidak lepas dari pengaruh situasi politik nasional yang berkembang di era reformasi. Dengan diberlakukannya sistem pemerintahan yang desentralistik, Kabupaten Malinau pun terbentuk di tahun 1999. Malinau kemudian dibangun dan berkembang sejalan dengan semangat desentralisasi tersebut. Dan di masa sekarang, seperti yang telah dikemukakan oleh Moeliono et al (2009), meski belum sepenuhnya ideal, desentralisasi telah memberikan jalan bagi kelompokkelompok etnis lokal untuk dapat memiliki peran yang relevan secara politik. Di sisi lain, berkembangnya Kabupaten Malinau, dengan segenap potensinya, juga menjadi magnet bagi penduduk dari luar Malinau untuk datang dan menetap. Maka tidak mengherankan apabila Malinau menjelma menjadi salah satu wilayah melting pot baru di provinsi Kalimantan Utara.

Kesejahteraan penduduk Kota Malinau makin membaik seiring dengan pembentukan Kabupaten baru Limberg et al (2005). Di sisi lain, ada pergeseran konsumsi oleh penduduk. Hal ini menyebabkan adanya perubahan yang tidak hanya terlihat pada kenaikan volume timbulan sampah, akan tetapi juga pada karakteristik timbulan sampah. Yaitu pergeseran dari sampah rural ke arah sampah urban/perkotaan. Ini sejalan dengan laporan Bank Dunia, dimana secara global timbulan sampah urban selalu meningkat. Diproyeksikan bahwa pada tahun 2025 produksi sampah akan meningkat menjadi 2,2 milyar ton sampah per tahun, sebagai perbandingan pada tahun 2012 produksi sampah perkotaan dunia adalah 1,3 milyar ton per tahun (Hoornweeg and Bhada Tata, 2012). Oleh karena itu, layanan pengelolaan sampah di Kota Malinau seyogyanya juga harus beradaptasi dan pengembangannya sebaiknya mengikuti perkembangan tersebut.

Masyarakat merupakan stakeholder utama dalam setiap program yang dicanangkan pemerintah, tidak terkecuali dalam perencanaan pengelolaan sampah. Dalam kacamata persampahan, peran masyarakat selayaknya tidak hanya dipandang sebagai penghasil timbulan sampah. Memandang masyarakat hanya sebagai pengguna, merupakan perspektif sempit yang justru mereduksi peran masyarakat itu sendiri. Mengapa demikian? Karena masyarakat memiliki aset krusial, entah itu pengetahuan, tradisi, ataupun mekanismemekanisme kolektif sebagai penunjang kehidupan bermasyarakat. Kesemuanya saling terkait membentuk suatu dinamika sosial. Dan dalam prakteknya, pengelolaan sampah sangat terkait dengan dinamika sosial ini, baik secara langsung maupun tidak langsung. Maka pemahaman terhadap dinamika di dalam 
masyarakat ini sangat esensial dalam merancang perencanaan pengelolaan sampah yang otimal. Terlebih di era good governance seperti saat ini, dimana paradigma pemberdayaan masyarakat dalam pemerintahan menjadi tuntutan. Tujuan penelitian ini adalah untuk mengetahui praktik-praktik yang dilakukan masyarakat Malinau Kota dalam pengelolaan sampah serta persepsi mereka terhadap layanan pengelolaan sampah yang telah dilakukan.

\section{METODOLOGI}

Penelitian dilakukan dengan metode deskriptif berdasarkan kajian yang dilakukan terhadap berbagai aspek yang bersumber dari data primer (penyebaran kuesioner dan wawancara) serta data sekunder. Penyebaran kuesioner ditujukan kepada 30 responden yang mewakili rumah tangga, serta dipilih secara acak. Aspek yang ditelaah meliputi aspek budaya masyarakat dalam membuang sampah, proses pemilahan sampah, proses pengumpulan sampah, pengangkutan sampah,pengolahan sampah, pemusnahan sampah sampai pada pembuangan atau pemrosesan akhir. Sedangkan untuk ruang lingkup penelitian dibatasi hanya di kecamatan Malinau Kota, Malinau Barat, dan Malinau Utara sebagai tiga kecamatan yang terpadat penduduknya.

\section{HASIL DAN PEMBAHASAN}

\section{A. Perilaku dan Inisiatif Masyarakat Terkait Penanggulangan Sampah}

Salah satu prinsip dalam pengembangan pengelolaan sampah di Indonesia adalah 3R yaitu Reduce (upaya mengurangi produksi sampah), Re-use (menggunakan kembali), dan Recycle (daur ulang) (Sakai et al, 2011), sebagaimana digariskan dalam Peraturan Menteri Pekerjaan Umum Republik Indonesia Nomor 03/PRT/M/2013 tentang Penyelenggaraan Prasarana dan Sarana Persampahan dalam Penanganan Sampah Rumah Tangga dan Sampah Sejenis Sampah Rumah Tangga. Oleh karena itu dalam penelitian ini, prinsip tersebut diintegrasikan pada saat melakukan kajian, terutama menyangkut perilaku dan inisiatif masyarakat terkait penanggulangan sampah.

\section{A.1. Perilaku terhadap penanggulangan timbulan sampah}

Berikut ini adalah tinjauan dari beberapa opsi perlakuan terhadap timbulan sampah.

a) Membuang sampah tidak pada tempat yang disediakan.

Masyarakat umumnya sudah cukup menyadari untuk membuang sampah pada tempat yang disediakan. Rata-rata masyarakat mengakui mereka sedapatnya menghindari untuk membuang sampah di tanah kosong ataupun di pinggir jalan, terlebih apabila lokasinya dekat dengan rumah. Hal ini karena masyarakat menghindari resiko aroma yang tidak sedap, masuk ke dalam rumah.

Di wilayah pemukiman umum yang cenderung urban, terutama di pinggir jalan utama, cukup jarang terlihat tumpukan sampah yang diletakkan begitu saja. Kalaupun ada, biasanya hanya timbunan kecil, tidak sampai menggunung. Fakta serupa juga dapat dilihat di lingkungan perkantoran dan sekolah. Demikian pula di area pemukiman rural, pemandangan seperti tumpukan sampah di pinggir jalan, atau ceceran sampah jarang terlihat.

Namun di area yang cukup ramai aktivitasnya, dimana timbulan sampah yang dihasilkan cukup besar, ada kecenderungan untuk lebih abai terhadap penanggulangan sampah. Misalkan di wilayah Jalan Pelabuhan Sebamban, kecamatan Malinau Kota, terdapat area pasar sporadis yang sangat ramai aktivitasnya. Ini merupakan wilayah pasar lama, yang sebenarnya telah direlokasi ke Pasar Induk oleh pemerintah setempat. Namun cenderung muncul kembali setelah ditertibkan. Disini terlihat di penanggulangan sampah relatif terabaikan. Di beberapa sudut, banyak terlihat tumpukan-tumpukan sampah yang penempatannya kurang tertib.

Kondisi demikian juga terlihat di lingkungan Pasar Induk. Pengumpulan sampah di TPS (Tempat Pembuangan Sampah) sentral cenderung kurang tertib. Sampah yang dikumpulkan dari kompleks pasar, kebanyakan dibuang di luar bak TPS. Akibatnya pekerja pengangkut sampah harus bekerja ekstra memindahkan tumpukan sampah tersebut ke dalam bak arm-roll truck, sebelum berangkat menuju TPA (Tempat Pembuangan Akhir).

b) Membuang ke sungai

Sementara itu masyarakat yang tinggal di dekat sungai, meski mengakui lebih sering membuang sampah ke TPS, namun juga mengakui kadang-kadang mereka masih membuang sampah ke sungai. Dalam prakteknya, kemungkinan frekuensi masyarakat membuang sampah ke sungai jauh lebih besar. Mengingat jika kita mengamati kondisi sungai Malinau, sampah yang mengapung di sungai sangat mudah dijumpai.

c) Membakar

Sebagian masyarakat kadang-kadang melakukan cara ini, namun bukan prosedur yang menjadi pilihan utama dalam memperlakukan sampah. Opsi membakar biasanya dilakukan pada sampah organik seperti daun-daun dari menyapu halaman, dan sampah an-organik seperti kemasan plastik.

d) Ditimbun dengan tanah

Penelitian ini menemukan bahwa perlakuan pada sampah dengan cara ditimbun tidak lazim dilakukan.

e) Sampah dikumpulkan lalu dibuang perorangan ke TPS terdekat.

Membuang sampah ke TPS secara perorangan merupakan perlakuan yang paling sering dilakukan 
oleh masyarakat Malinau, terutama yang tinggal di wilayah yang relatif urban, dan terjangkau layanan pengelolaan sampah.

f) Sampah dikumpulkan secara komunal.

Dalam sistem pengangkutan sampah komunal, ada mekanisme pengumpulan sampah dari sejumlah kepala keluarga yang ditentukan, sebelum akhirnya dibuang ke TPS. Biasanya pengangkutan komunal terbentuk dalam lingkup RT (Rukun Tetangga), RW (Rukun Masyarakat), ataupun dalam satu rute khusus yang melewati beberapa rumah yang telah disepakati. Biasanya ada pembayaran iuran sesuai kesepakatan bersama. Dari hasil observasi dan interview, khususnya di wilayah yang mendapat layanan pengangkutan sampah, masyarakat Malinau belum memiliki inisiatif untuk membentuk sistem pengangkutan sampah seperti ini. Mereka karena merasa sudah cukup hanya bergantung pada layanan pengangkutan sampah dari Dinas Tata Kota.

\section{A.2. Inisiatif dalam upaya pengurangan dan pemanfaatan sampah}

Bagaimana dengan inisiatif dari masyarakat Malinau sendiri terkait upaya-upaya pengurangan dan pemanfaatan sampah? Dalam penelitian ini, penyusun merangkai informasi mengenai inisiatif masyarakat terkait sampah dengan mengaitkannya dengan karakteristik masyarakat Malinau itu sendiri.

\section{a) Pemilahan Sampah Organik dan Non-Organik}

Praktek-praktek pemisahan sampah organik dan Non-Organik ternyata sudah dilakukan oleh sebagian masyarakat Malinau. Dan yang menarik adalah ada beberapa faktor pendorong masyarakat dari latar belakang berbeda dalam melakukan praktek pemisahan ini.

Praktek memisahkan sampah organik dan nonorganik dilakukan untuk memberi pakan hewan ternak seperti ayam. Pakan hewan ternak diperoleh dari sisa-sisa makanan dan buah-buahan. Disini terlihat masyarakat melakukan pemisahan dengan alasan praktikal. Kebiasaan ini sesungguhnya merupakan praktek warisan dari pola kehidupan agraris yang masih mengakar dalam aktivitas keseharian masyarakat Malinau. Hal ini bahkan masih terlihat dari masyarakat yang tinggal di wilayah relatif urban. Fakta ini selaras dengan temuan Deka et al (2014), yang menyatakan bahwa di Asia Tenggara, praktek peruntukan sampah dapur (potongan sayur dan kulit buah) dan sisa makanan untuk pakan ternak sesungguhnya sudah lazim dilakukan turun temurun. Alasan kepedulian lingkungan kurang menjadi motivasi dalam praktek pemisahan yang mereka lakukan. Kebiasaan ini tentunya sangat baik untuk terus dipertahankan. Praktek ini juga lebih ramah lingkungan, karena sampah makanan langsung diberikan kepada ternak, tanpa harus melewati pemrosesan khusus, sehingga jejak emisi karbon sangat kecil (Salemdeeb, 2016).

Sementara itu, di institusi sekolah, motivasi menjaga lingkungan justru menjadi faktor utama yang mendorong dilakukannya praktek pemilahan sampah. Salah satu sekolah yang dikunjungi, yaitu SMA Negeri 1 Malinau, sudah berjalan program Adi Wiyata. Program ini visinya adalah mewujudkan sekolah yang peduli lingkungan, bersih, dan indah (Puspita R, 2015). Salah satu kegiatannya adalah mendidik pelajar untuk membuang sampah organik dan non-organik pada wadah yang berbeda. Program Adi Wiyata di SMA Negeri 1 Malinau bahkan pernah mendapat bantuan dari WWF Indonesia. Bentuk bantuan berupa tempat sampah organik dan non-organik untuk setiap ruang kelas. Sejauh ini program dinilai efektif, satu-satunya kendala adalah justru TPS di depan sekolah bukan TPS yang memisahkan sampah organik dan non-organik.

b) Menggunakan kembali kemasan yang masih bisa digunakan

Secara praktek cukup sederhana, yaitu menggunakan sisa produk khususnya kemasan untuk digunakan kembali. Meski relatif gampang dilakukan ternyata masyarakat Malinau jarang melakukannya. Umumnya mereka lebih sering langsung membuang kemasan yang tidak terpakai ketimbang menggunakan kembali.

c) Mendaur ulang

Praktek mendaur ulang pada dasarnya memang membutuhkan niat, karena ada usaha yang harus dikeluarkan. Maka tidak mengherankan apabila masyarakat Malinau relatif tidak melakukan kegiatan mendaur ulang sampah. Untuk mendorong praktek ini, memang perlu adanya upaya pembinaan lebih serius.

\section{d) Menghemat penggunaan kemasan plastik}

Praktek ini juga salah satu praktek yang cukup mudah dilakukan. Sebagian masyarakat ada yang telah mempraktekkannya, namun sayangnya sebagian besar mash belum melakukan praktek ini secara konsisten.

\section{B. Persepsi Masyarakat Terhadap Layanan Pengelolaan Sampah Kota}

Opini masyarakat mengenai layanan pengelolaan sampah di Malinau cukup beragam. Dari sisi masyarakat sendiri, latar belakang khususnya wilayah domisili dan lokasi pekerjaan, sangat mempengaruhi bagaimana opini masyarakat terbentuk. Masyarakat pun cukup dapat menilai dari masing-masing aspek yang mendukung layanan pengelolaan sampah di Kabupaten Malinau.

\section{B.1. Sarana dan prasarana}

a) Persepsi mengenai TPS 
Tingkat kepuasan masyarakat terhadap TPS, umumnya banyak tertuju pada kondisi dan jumlah TPS yang tersedia. Secara umum, fasilitas TPS dinilai pada ambang penilaian terendah atau sangat kurang. Kurangnya jumlah TPS yang tersedia di pinggir jalan menjadi keluhan yang paling dominan. Opini mengenai kurangnya TPS cukup seragam di kecamatan Malinau Kota, Malinau Barat, dan Malinau Utara. Sementara untuk kecamatan Mentarang dan Malinau Selatan, layanan pengelolaan sampah memang belum menjangkau dua kecamatan tersebut.

Kurangnya TPS bukan hanya terkait masalah kapasitas sampah yang dapat tertampung. Namun terkait pula pada masalah kemudahan akses membuang sampah. Semakin jauh radius TPS dari tempat tinggal masyarakat, semakin besar pula keengganan masyarakat membuang sampah di TPS. Tercatat, ada 48 TPS yang tersebar di kecamatan Malinau Kota, Malinau Barat, dan Malinau Utara (BPS Kabupaten Malinau, 2013). Untuk mengantisipasi kurangnya TPS, masyarakat secara swadaya menyediakan wadah seadanya dari tong plastik, ember, dll. Wadah ini umumnya diletakkan di depan rumah atau di pinggir jalan terdekat, untuk kemudian dikumpulkan oleh armada pengangkut.

Selain jumlah TPS yang minim, peletakan TPS juga lebih banyak terkonsentrasi di pinggir jalan utama, sedangkan jalan-jalan yang lebih kecil untuk memasuki pemukiman masyarakat, TPS jarang tersedia. Hasil observasi dari surveyor mengkonfirmasi keluhan masyarakat tersebut. Pengamatan di lapangan menunjukkan bukan hanya TPS lebih banyak terkonsentrasi di pinggir jalan utama, tetapi juga lebih terkonsentrasi pada pusat pertumbuhan ekonomi, terutama di kecamatan Malinau Kota. Semakin jauh satu wilayah dari kecamatan Malinau Kota, akan semakin jarang TPS resmi terlihat, lebih banyak TPS swadaya masyarakat.

Sedangkan mengenai kondisi TPS yang ada, sebagian masyarakat mengeluhkan wadah TPS yang tidak tertutup. Ini memungkinkan hewan liar seperti anjing leluasa mengorek timbunan sampah, akibatnya sampah berserakan di luar TPS. Kondisi ini dinilai masyarakat selain tidak higienis juga merusak keindahan.

Masyarakat yang berprofesi sebagai pedagang di Pasar Induk memiliki opini tersendiri mengenai TPS. Secara umum mereka menilai, kondisi di Pasar Induk cukup memprihatinkan. Jika masyarakat di pemukiman umum hanya mengeluhkan kurangnya TPS, para pedagang mengeluhkan tidak adanya TPS di dalam kompleks pasar. Fasilitas penampungan sampah yang ada di Pasar Induk hanya satu TPS sentral, untuk menampung seluruh sampah dari pasar. Pedagang terpaksa menyediakan wadah sampah individual sendiri dengan kondisi seadanya, serta dengan peletakan yang tidak teratur.

b) Persepsi mengenai armada pengangkutan

Masyarakat Malinau relatif tidak banyak menyoroti aspek kondisi armada pengangkutan. Hal ini disebabkan aspek ini kurang bersentuhan dengan kepentingan masyarakat. Dalam artian, asalkan sampah terangkut, bagaimana kondisi armada pengangkut itu sendiri tidak menjadi persoalan. Tercatat Kabupaten Malinau memiliki tujuh armada berupa truk sampah untuk melayani pengangkutan sampah (BPS Kabupaten Malinau, 2013). Meski demikian, beberapa masyarakat cukup kritis dengan kondisi armada pengangkutan. Mereka menilai kondisi sebagian besar armada pengangkutan sesungguhnya kurang layak, dan perlu direvitalisasi. Faktor ketidaklayakan disebabkan oleh penggunaan jenis kendaraan. Contohnya penggunaan pick-up yang sebenarnya bukan ditujukan untuk mengangkut sampah. Kondisi bak pick-up yang terbuka, selain memungkinkan sampah yang diangkut menyebarkan aroma tidak sedap ketika melalui jalan raya, dan memungkinkan adanya sampah yang tercecer. Selain kondisi armada, jumlah armada pengangkutan yang ada saat ini juga dianggap kurang.

\section{c) Persepsi mengenai TPA}

Secara umum, masyarakat relatif tidak menyoroti isu TPA. Faktor lokasi TPA di Sempayang yang cukup jauh dari pusat pemukiman, menyebabkan sebagian besar masyarakat kurang memiliki informasi tentang TPA. Kepentingan sebagian besar masyarakat tidak berbenturan langsung dengan keberadaan TPA. Namun demikian, ada laporan bahwa masyarakat di sekitar TPA sempat menyampaikan keluhan. Masyarakat mengeluh dengan adanya kebocoran lindi (air dari sampah) yang sampai hingga ke pemukiman mereka. Meski begitu, belum diketahui seberapa besar dampaknya ke masyarakat akibat dari kebocoran ini.

\section{B.2. Sistem layanan/operasional}

Tingkat kepuasan masyarakat Malinau terkait sistem layanan pengelolaan sampah di Malinau cukup beragam, dari yang menganggap sangat kurang hingga yang menganggap sudah baik. Dalam hal ini, kepuasan lebih ditekankan pada efektivitas dan kedisiplinan pengangkutan sampah. Umumnya masyarakat mengakui bahwa armada pengangkutan yang ada cukup disiplin. Setiap pagi sebagian besar sampah dapat terangkut. Namun demikian, hal tersebut bukannya tanpa kritik. Seringkali ada keterlambatan dalam pengangkutan sampah. Selain itu, sebagian masyarakat beropini bahwa frekuensi pengangkutan sampah perlu ditingkatkan menjadi dua kali sehari. Alasannya agar sampah tidak terlampau lama berada di TPS. Mengingat TPS tidak memiliki tutup, sehingga bila dibiarkan terlalu lama akan menimbulkan bau tak sedap, dan lebih besar kemungkinan mengundang hewan liar.

Hal lain yang menjadi kritik dari masyarakat adalah tidak adanya jadwal pengangkutan sampah di hari libur, terutama hari Minggu. Hal ini mengakibatkan menumpuknya sampah di hari-hari tersebut. Implikasinya adalah membengkaknya volume sampah yang harus 
diangkut pada hari berikutnya. Sehingga pekerja pengangkut harus bekerja ekstra agar seluruh sampah dapat terangkut. Dan apabila kondisinya sudah melebihi kapasitas, ada saja sisa sampah yang tidak terangkut, dan baru dapat terangkut di hari berikutnya.

Di Pasar Induk, seperti telah disebutkan di atas, terdapat satu TPS sentral untuk menampung seluruh sampah dari kompleks pasar. Rutinitas pengangkutan sampah di TPS sentral ini dianggap sudah baik oleh pedagang. Namun senada dengan keluhan masyarakat di pemukiman, mereka menilai perlu adanya jadwal pengangkutan sampah di hari-hari libur.

Keluhan utama dari para pedagang adalah tidak rutinnya pengumpulan sampah dari kompleks pasar untuk kemudian diangkut ke TPS sentral tersebut. Menurut pengakuan pedagang, ini tidak hanya terjadi di hari libur, akan tetapi juga di hari kerja. Dengan kondisi tersebut, tidak mengherankan bila tumpukan-tumpukan sampah yang terbengkalai di kompleks Pasar Induk menjadi pemandangan biasa. Kurang disiplinnya pengumpulan sampah di kompleks pasar juga berimbas pada proses pengangkutan sampah di TPS. Pengumpulan sampah yang tidak rutin menyebabkan penumpukan sampah berlebihan di TPS sentral. Yang tentu saja ini menyulitkan kinerja awak pengangkut sampah yang harus bekerja ekstra.

Ada beberapa hal yang disorot oleh masyarakat pedagang sebagai faktor penyebab kurangnya disiplin dari tenaga kebersihan dan pengumpul sampah di kompleks pasar tersebut. Faktor pertama adalah kurangnya pengawasan dan koordinasi dari pihak terkait, khususnya pengelola pasar. Faktor kedua adalah proses perekrutan tidak memperhatikan aspek produktivitas dari calon pekerja. Misalkan perekrutan orang yang telah lanjut usia, sementara pekerjaan tersebut menuntut kekuatan dan ketahanan fisik yang baik.

\section{B.3. Sosialisasi program penanggulangan sampah}

Dari hasil interview dengan masyarakat Malinau, sebagian besar masyarakat mengaku tidak pernah mengetahui adanya kegiatan sosialisasi dari pemerintah terkait program penanggulangan sampah. Tentu saja karena ketidaktahuan ini, ketika responden ditanya bagaimana tingkat kepuasan mereka terhadap kegiatan sosialisasi dari pemerintah, sekitar $66 \%$ menjawab kurang puas. Masyarakat sendiri menyatakan menyambut positif apabila ada kegiatan sosialisasi terkait penanggulangan sampah.

\section{B.4. Ketegasan dalam Penerapan Sanksi}

Dalam hal penanggulangan sampah, Masyarakat Malinau umumnya cukup mengetahui perilaku yang dianggap kurang baik, seperti membuang sampah sembarangan. Namun apabila dikaitkan dengan ketegasan pemerintah, sebagian besar masyarakat berpendapat tidak ada korelasi positif antara ketegasan penerapan sangsi dengan kesadaran masyarakat untuk tertib membuang sampah. Masyarakat menilai apabila masyarakat disiplin membuang sampah sesuai aturan, itu adalah murni karena didorong kesadaran sendiri, bukan karena penegakan sangsi. Ini masuk akal, karena masyarakat memang tidak pernah mendengar adanya kasus penerapan sanksi hukum terhadap oknum yang membuang sampah tidak sesuai aturan. Masyarakat sendiri cukup menyambut positif apabila penegakan sangsi terhadap oknum yang melanggar aturan membuang sampah, dilaksanakan secara serius.

\section{B.5. Penetapan retribusi sampah}

Masyarakat Malinau dikenakan iuran sampah per bulan, yang pembayarannya bersamaan dengan iuran layanan air bersih. Persepsi masyarakat terhadap penetapan iuran ini cenderung negatif (58\%). Sebagian besar menyatakan ketidakpuasannya terhadap penerapan iuran sampah. Alasannya beragam, ada yang karena dilatarbelakangi keengganan masyarakat itu sendiri dengan pembebanan iuran sampah. Mereka beranggapan bahwa pembiayaan pengelolaan sampah merupakan tanggung jawab pemerintah. Sebagian lain karena melihat masih kurang memadainya sarana dan prasarana yang ada. Meski demikian, sebagian besar masyarakat Malinau menyatakan bersedia membayar iuran pengelolaan sampah. Dengan catatan, besaran iuran yang dibebankan masih berada pada tingkat kewajaran. Dalam studi ini, iuran sampah yang dinilai wajar adalah pada kisaran di bawah Rp. 20.000 per bulan. Ini berarti, ada peluang meningkatkan sumber pembiayaan dari iuran masyarakat. Tentu saja dengan harapan bahwa ada peningkatan mutu layanan pengelolaan sampah yang signifikan, sepada dengan besaran iuran tersebut.

\section{Faktor Pendorong dan Penghambat Partisipasi Masyarakat Dalam Pengelolaan Sampah}

Pengelolaan sampah dengan manajemen yang lingkupnya meliputi wilayah dengan skala Kabupaten, tentunya membutuhkan partisipasi masyarakat untuk menjamin efektivitasnya. Berikut adalah rangkuman dari observasi terhadap dinamika sosial terkait pengelolaan sampah, dengan fokus kepada hal-hal yang dapat berpotensi menjadi faktor pendorong maupun penghambat partisipasi masyarakat:

1. Kesadaran masyarakat dalam membuang sampah

- Faktor pendorong. Secara normatif, masyarakat cukup menyadari pentingnya menjaga kebersihan, khususnya dalam hal kesadaran membuang sampah pada tempatnya. Perilaku membuang sampah sembarangan dipandang tindakan yang melanggar etika. Masyarakat juga sudah mampu mengkritisi kinerja layanan pengelolaan sampah yang ada saat ini.

- Faktor penghambat. Meski sudah ada kesadaran soal membuang sampah. Secara umum kesadaran ini kurang terinternalisasi dalam tatanan masyarakat. Dikuatkan dengan tidak adanya mekanisme sangsi sosial terhadap perilaku membuang sampah yang tidak taat aturan. 
2. Pengelolaan sampah swadaya

- Faktor pendorong. Pengelolaan sampah yang dilakukan dalam unit terkecil masyarakat, yaitu di tingkat keluarga, cukup baik. Meskipun, inisiatif ini masih bersifat konvensional, seperti membuang sampah pada tempat yang disediakan. Sedangkan inisiatif-inisatif pemisaha, pemanfaatan dan daur ulang sampah, meski sudah ada namun belum dilakukan secara signifikan

- Faktor penghambat. Masyarakat belum mengenal dan mempraktekkan manajemen pengelolaan swadaya yang bersifat komunal/kolektif.

3. Kesediaan membayar retribusi

- Faktor pendorong. Masyarakat secara umum bersedia untuk membayar retribusi pengelolaan sampah, dalam tarif wajar. Meski ada sebagian yang kurang setuju, namun tetap menyatakan bersedia untuk membayar.

- Faktor penghambat. Tidak teridentifikasi.

4. Kesadaran untuk berpartisipasi dalam program pengurangan dan pemanfaatan sampah yang dicanangkan pemerintah

- Faktor pendorong. Secara verbal, masyarakat umumnya menyatakan kesediaan dan bahkan antusiasme tinggi untuk berpartisipasi, jika pemerintah mencanangkan program pengurangan dan pemanfaatan sampah.

- Faktor penghambat. Masih kurangnya sosialisasi pemerintah terkait pengelolaan sampah selama ini, menyebabkan sulitnya mendapat gambaran menyeluruh bagaimana kesadaran verbal ini teraktualisasi di lapangan, di setiap lapisan masyarakat. Namun secara parsial, misalnya di lingkungan sekolah, program serupa terbukti cukup efektif dalam hal pelibatan unsur masyarakat.

\section{KESIMPULAN}

Dari segi praktik pengelolaan sampah, masyarakat Kabupaten Malinau relatif telah sadar akan pentingnya menjaga kebersihan. Meski belum sepenuhnya terimplementasi dalam tindakan. Membuang sampah pada tempat yang telah disediakan sudah dilakukan oleh sebagian besar masyarakat. Perilaku keliru dalam membuang sampah yang paling umum dilakukan adalah membuang sampah ke sungai, serta di fasilitas umum yang ramai seperti pasar. Selain itu, pengelolaan sampah secara komunal relatif belum dilakukan. Di sisi lain, ada pula praktik positif yang telah dilakukan masyarakat Malinau sejak lama, yaitu pemanfaatan sampah dapur dan sisa makanan menjadi pakan ternak. Di samping itu, praktik pengelolaan sampah swadaya yang terorganisir dengan baik dapat ditemukan di sekolah-sekolah.

Dalam hal layanan pengelolaan sampah kota yang dilakukan dinas terkait, masyarakat umumnya mengeluhkan kurangnya jumlah TPS yang layak serta perlunya peningkatan frekuensi dalam kedisiplinan dalam pengangkutan dan pengumpulan sampah ke TPA. Untuk pengembangan layanan pengelolaan sampah ke depan, pemerintah setempat sebaiknya tidak hanya terpaku pada penyediaan sarana dan prasarana saja, namun perlu pula melakukan upaya lebih untuk mendorong partisipasi masyarakat yang lebih besar. Mengingat prinsip pengelolaan sampah secara 3R mengisyaratkan partisipasi masyarakat dalam melakukan pemilahan dan pengumpulan sampah, di tingkat rumah tangga.

\section{DAFTAR PUSTAKA}

Badan Pusat Statistika Kabupaten Malinau. (2013). Malinau Dalam Angka. Kerjasama Badan Perencanaan Pembangunan Daerah Kabupaten Malinau dengan Badan Pusat Statistik Kabupaten Malinau.

Deka, R. P., , Delia Grace, Ma Lucila Lapar, Johanna Lindahl. (2014). Sharing Lessons of Smallholders' Pig System in South Asia and Southeast Asia: a Review. National Conference on 18 Opportunities and strategies for Sustainable Pig Production organized by the ICAR-National Research Centre on Pig, Rani, Guwahati, India, 20-21 Dec 2014

Hoornweg, D. dan Bhada-Tata, P. (2012). What a Waste: A Global Review of Solid Waste Management. Urban Development Series. Urban Development \& Local Government Unit. World Bank, Washington DC.

Limberg, G et al. (2005). Profil Desa-desa di Kabupaten Malinau: Kondisi Sosial Ekonomi Desa-desa. Center for International Forestry Research, Jakarta.

Moeliono, M. Wollenberg, E. dan Limberg, G. (2009). The Decentralization of Forest Governance. Earthscan, UK.

Puspita R, Heny. (2015). Adiwiyata Mewujudkan Sekolah yang Berbudaya Lingkungan. Warta BP2SDM: Adiwiyata E-magazine. Badan Penyuluhan dan Pengembangan Sumberdaya Manusia Kementerian Lingkungan Hidup dan Kehutanan.http://bp2sdm.menlhk.go.id/emagazine/att achments/article/59/1.Adiwiyata\%20e\%20magazine\%20_5.pdf (diakses pada tanggal 5 Januari 2017).

Sakai, S., Yoshida, H., Hirai, Y. et al. 2011. International comparative study of $3 \mathrm{R}$ and waste management policy developments. J Mater Cycles Waste Management (2011). Vol 13: pp 86 102.https://doi.org/10.1007/s10163-011-0009-x.

Salemdeeb. R, zu Ermgassen EKHJ, Kim MH, Balmford A, Al-Tabbaa A. (2016). Environmental and Health Impacts of Using Food Waste as Animal Feed: A Comparative Analysis Of Food Waste Management Options, Journal Of Cleaner Production (2016), Doi: 10.1016/J.Jclepro.2016 
